\title{
Corporate Communication through the Campaign of Consuming Jamu
}

\author{
Fitria Widiyani Roosinda \\ ORCID iD: 0000-0003-4048-0451, Universitas Bhayangkara Surabaya, Jl. Ahmad \\ Yani 114, Surabaya, East Java 60231, Indonesia \\ *Corresponding author, email: fitria@ubhara.ac.id
}

\begin{abstract}
This research is motivated by the phenomenon of increasing consumption of emponempon products by the community since the emergence of the Covid-19 pandemic in Indonesia. Empon-empon is ones of jamu (traditional herbal drink) which the ingredients is consisting of ginger, turmeric and other spices. The community believes that empon-empon is able to prevent from Covid-19. This contributes to build simultaneous awareness of the community and ultimately creates a lifestyle of consuming jamu. This situation is used by jamu corporate (Jamu Iboe) to conduct campaigns to drink jamu to increase sales of their products. This study aims to determine the campaign strategy for drinking jamu, how the community responds to the campaign, and what jamu products are most in demand. Qualitative descriptive is the method used in this research by conducting in-depth interviews. This research concludes that jamu corporates carry out their corporate communication program strategies through social media by inviting people to drink jamu and unite to prevent and fight Covid-19. The public response to jamu is very high, compared to before the pandemic. The most popular herbs are ginger, white turmeric, temulawak and sambiloto.
\end{abstract}

Keywords: Corporate Communication, Campaign, Consuming Jamu, Covid-19.

\section{Introduction}

Јати is originated from natural ingredients belonging to the heritage of Indonesian ancestors and this is passed down from generation to generation to maintain health. In several cities, there are many jamu sellers who often go around selling it with various variants to the connoisseurs of these healthy drinks. On the daily sale of jamu is determined by consumer demand (Wiedosari et al., 2020). Jamu is very common by Indonesian people, consuming jamu is considered as a traditional medicine. This jamu is made from several herbs that have good properties for the body and health. Most countries in Asia have used jamu as a traditional medicine, the society also give it another name, that is alternative medicine (Setiawan et al., 2018). Jamu is identical to the stigma of medicine and has a bitter taste, in contrast to current drinks that taste better and suitable for the millennial. It is also identical with ancient things that are only consumed by old people, rather than millennial. That stigma are the main obstacle in the development of jamu, innovation needs to break down the negative stigma about it. Product design is important so that herbs can reach young people, how to package jamu to be more up-to-date, for example, as coffee trends are developing rapidly lately. Variants of coffee flavor that was originally only bitter, as the times evolved into various types and flavors (Pradana, 2019).

The World Health Organization (WHO) welcomes innovations around the world including repurposing drugs, traditional medicines and developing new therapies in the search for potential treatments for Covid-19. WHO recognizes that traditional, complementary and alternative medicine has many benefits (Pradana, 2019). A

Article History: Received May 07, 2020; Revised April 12, 2021; Accepted July 16, 2021; Published September 20, 2021 
campaign is an action and an effort that has the aim of gaining support, this campaign effort can be carried out individually or in an organized group. The campaign of consuming jати carried out by Jamu Iboe is an activity that makes people aware of the importance of consuming jamu and its benefit for the body. Jamu is a processed drink that made from original plants which has no chemical mixture in its manufacture. Jamu also has a traditional nickname, because it has existed since ancient times (ancestors' time), so many jamu with certain potion that has been used for hundreds years still today as a healthy drink (Lestari \& Simarmata, 2018). Society believes that consuming jamu will get many benefits, namely as a disease prevention and also to maintain the immune system to stay healthy. That way, market demand for jamu is currently increasing. Nowadays, jати is no longer regarded as an ordinary drink; it has experienced a rotation in dosage forms and benefits that jamu is easy to enjoy with practical and usefulness as a healthy lifestyle. Starting to get used to consume jamu from our self, and then invite the family, the environment, and the society.

In traditional medicine, the prevention of infectious diseases relies on the use of botanical detoxifiers, immune boosting remedies, natural antioxidants, plant haematinics and spices. Based on the fact that Covid-19 is a viral infection, the use of antiviral medicinal plants might be useful in itsprevention and management. Considering the symptoms of Covid-19 infection--fever, cough, body pain, flu, cold and shortness of breath; plants with antimalarial effect, cough remedy, herbal analgesic and medicinal plants with therapeutic effects in respiratory tract infections could be useful in the prevention of Covid-19 infection (Gbadamosi, 2020). Furthermore, the doctrine of signatures might play an important role in the choice of botanicals for the prevention and management of Covid-19 infection (Lestari \& Simarmata, 2018). People with low immunity are more prone to this world pandemic named as Covid-19. To help or boost the immunity, the various Herbs play a vital role by promoting beneficial bacteria in the body. Various vitamins like C, D, and $\mathrm{E}$ are investigated to provide important aspects for improving immunity. Herbs like Withania somnifera, Tinospora cordifolia, Panax ginseng, Emblica officinalis, Zingiber officinale, Curcuma longa, Allium sativum, Aloe barbadensis, Azadirachta indica, Ocimum tenuiflorum, Echinacea perpurea and many more. While other vegetables are rich in vitamin $\mathrm{C}$ and are good for immunity (Eapen, 2021). Proper nutrition and hydration improve health and immunity, they are not magic bullets. People living with chronic illnesses who have suspected or confirmed Covid-19 may need support with their mental health and diet to ensure they keep in good health. Future aspects of this account for more research which is needed significantly on physical behaviors or exercises and their role in immunity-related issues thus preventing Covid-19 (Namdeo, 2021).

Slowly but sure, the notion of jamu as an ancient jamu began to shift in the society's mind. Stepping on for more than a century of its existence, Jamu Iboe is increasingly innovative and responsive in fulfilling the healthy lifestyle of modern society. Starting from product variants, sales venues, presentations, and flavors, everything is designed more modern and innovative; so that it can be served to all walks of life from children to parents. Jamu Iboe continues to be committed to improve the standard of living that is of higher quality from generation to generation. Jamu as a tradition has been trusted by the community to maintain the immune system to be always healthy. Many consumers still consume jamu by brewing; it is because in order to taste more prominent, they also assume that steeping jamu powder is more useful. In this modern era, Jamu Iboe still provides hundreds of products with different shapes and 
variations, such as granules, powders, capsules, and liquids. There are two kinds of products from Jamu Iboe, liquid for external medicine (telon oil and eucalyptus oil) and liquid for internal medicine which are drunk in bottles and sachets.

Consumer demands that tend to be practical, encourage jamu company to develop its products not only in powder, but also in liquid, pills, capsule extracts until health drinks, so that jamu can be consumed in an easier way. The increasingly of market demand, Jamu Iboe continuously makes various innovations to fulfill the consumers' need. The development of distribution continues to be carried out, various supporting facilities such as increasingly strengthened fleets and widened markets, ranging from the domestic market, such as jamu depots, grocery stores, pharmaceutical stores, drug stores, pharmacies, and convenience stores to the international market.

Many people are reluctant to consume jamu because of its images that are old, ancient, have a bitter taste, and are outdated. Due to those assumptions, jamu does not become a lifestyle in modern society including millennial. it will have an effect on the extinction of jamu, if that is not handled fully, and therefore it needs repositioning to change that view (Tamara, 2017).

The demand for jamu increases along with public awareness in maintaining the immune system to deal with the Coronavirus. A number of jamu producers admit that there is an increase in demand and sales. Since the Covid-19 pandemic has become a problem for the society, products with claim to "be able to prevent" are in demand by the public, including empon-empon to jamu that they consume in a single drink. That way, the increasing demand for jamu will attract the society's attention and make it aware of the importance of consuming jamu as a form of efforts to prevent viruses and increase our immunity. That way, the innovations of jamu more developed that make it fast, easy, and practical for consumption. Covid-19 has had a significant impact on the economic sector, but the merchants selling jamu are increasingly in demand. They usually go around selling their products until night. Nowadays, with the presence of Covid-19, jати is increasingly sought everywhere. Meanwhile, the prices of ingredients for making it such as kencur, ginger, turmeric, brotowali, tamarind, and others has increased; it because the higher society's demand (Nawir, 2020).

Meanwhile, public relations is about how to build communication in society continued that is aimed at gaining good intentions, mutual understanding, trusting, fostering positive public opinion, public supporting, those will lead to the organization reputation (Trimanah \& Wulandari, 2018). The importance of public relations as a medium is used by corporates to communicate with the society. In globalization era, corporates must actively use technology through digital media. The public relations' function will be increasingly needed by corporates, where public relations as the beginning of corporate communication functions formation. So, corporates must always see this as a new strategy in disseminating information to the public. It can also be used as a method of disseminating new corporate communication information from experts in an organization that aims to advance an organization (Mulyani et al., 2015). Corporate communication becomes important in every company to obtain the company's goals that have been planned, and in its implementation all must be related to one another. In the current scope of corporations, corporates rely on the response of the community whether it is successful or not.

The existence of stakeholders is very important in a company that is because his opinion becomes an important point to make the company successful in the long term, so leaders must pay attention to this well. Then, the opportunity for corporate 
communication to take place in social media (Juwita, 2017). Corporate communication is an effort to publicize the organization through communication to external and internal parties. There is a company policy that has a vision and mission for the stakeholders which is very crucial. Corporate communication confers as a communication function in receiving the messages (Pahlevi, 2017).

Corporate communication is an integration of two functions, namely as a function of public relations and also marketing. The function of public relations is focusing on the developing a brand image and positive image of the product to be marketed. Whereas the function of marketing is focusing on sales results that aim for financial gain, besides that marketing is also oriented towards production and sales which is continued with product marketing. In the marketing process, this requires publication activities which will be realized by public relations. Corporate communication forms the company's identity for communication that explains the company, such as name, vision, mission, logo, products, services, which includes regulating employee costumes; those made so that communication can be conveyed to the society. Furthermore, society will make an opinion about the messages from the company, thus forming a corporate image (Syaifuddin, 2018). The concept that is constructed in corporate communication is in the form of an integrative communication structure (two way communication) between stakeholders and the company. Corporate communication becomes an arrangement that can regulate all forms of communication precisely (Handes, 2019).

Campaign activities that are arranged in a balanced, open, tolerance, no time limit, there are programs that are planned, persuaded, understand communicators and positive suggestions will be a well organized communication activity, which aims to create a planned impact on the target society and in a predetermined time period. The society who become the target must be treated the same as the other targets (Perbawasari et al., 2016). Public relations campaign is an effective way that can be done by all corporates to get closer to the society, in addition to the message to be conveyed, the company's image can also develop.

Several types of public relations campaigns that can be conducted by corporates, namely: first, product oriented campaigns, the campaign is focused on the product, usually there is in the scope of business where the society can be introduced at the same time with the new product; second, candidate oriented campaigns, campaign is focused on the candidates in an election, this related to political matters and are motivated to provide political interests; third, ideologically or cause oriented campaigns, focusing on planned and specific objectives, for example social problem campaigns for behavior change; and fourth, attacking campaign, this campaign is attacking each other, such as attacking each other on the amount of data and facts which will subsequently be debated, this is a negative campaign (Daud et al., 2017)

To carry out a campaign as a form of work program campaign, daily activities, information, and other objectives that introduce the level of awareness or even seek support from the public as a target society while influencing and persuading the society in accordance with the intended destination. As for the public relations campaign, it has an important role as a practitioner, the communicator between the company and its audience, and vice versa (Muges, 2018). Demanding changes in information in modern times, the emergence of online media makes corporates must have a new strategy to be able to communicate with the public. Becomes a great opportunity for online media or social media to deliver the company campaigns as the development of a good image and guide the society opinions (Firmansyah et al., 2017) 
The role of the public relations of a team becomes important, namely as the design of this digital campaign program to determine goals, target audiences, opinions that are built, measurable goals, planned activities, implement the program that has been determined next until there is an evaluation of the program. The process becomes important which public relations activities are directed management activities from the planning stage to the evaluation (Fernandha, n.d.). Digital campaign is a mixture of two words, campaign with digital media, and besides that it also has its own meaning. Campaigns that use the internet as a medium, in their development have an influence on the campaigns that have been exist, integrated media support each other (Hayuningrat \& Chandra, 2019). Communication technology has developed rapidly so that it has changed society's attitudes and mentality. Mental and attitudes changes are caused by the ease of getting information quickly and instantly (Widiyani Roosinda \& Alfraita, 2020).

Technology can be a good connector in digital campaigns conducted through social media. In addition to its wider dissemination and targeting all people, also in terms of practicality during the Covid-19 Pandemic, it greatly helped public relations to conduct its campaign. A digital campaign is used by a company to persuade the society. This has succeeded in attracting the society's attention, and then it has become examples for other corporates. The generation born above 1990 is a native digital generation. This generation is introduced early on with the latest media technology or has been exposed to new media (online media), so they have thoughts that are influenced by online media. They prefer online media than printed media, television, and even radio to search and find information. That way, this generation tends to interact frequently with social networks and rarely interact directly. This native or young generation is more often exposed to social media compared to conventional media.

\section{Methods}

The research is used descriptive qualitative method. Qualitative research methods is used to examine scientific topics where the writer holds the important part, as well as the incorporation of data collection techniques, then the inductive data is analyzed, and the results emphasize the definition rather than leveling (Sugiyono, 2015). Interviews were conducted with Perry Angglishartono (Product Group and Public Relations Manager at Jamu Iboe) to find the answers of research questions, such as the campaign program of consuming jamu, public response towards jamu, and the kind of jamu that are most sought after by the society. The results of the analysis are done by reducing the data, where a technique chooses the important discussion, makes the focus and looks for themes and patterns. The data presentation is arranged systematically with the existing relationship patterns presented in the form of exposure pictures. Then, the conclusion explains the whole picture of the research object and the process of combining all data obtained into one. Finally, describing in a qualitative narrative all the data findings from the interviews.

\section{Results}

The Campaign of Consuming Јати as a Corporate Communication Program

Traditionally, place marketing campaigns can be described using a linear model of communication, in which a source is delivering a message to a receiver. However, the unique characteristics of the social media turn web users from passive audience into active participants (Ketter \& Avraham, 2012). The campaign of consuming jamu is 
carried out through social media. The consideration of using social media is aimed at getting the message delivered to spread throughout the society. Jamu company invites the public to support hospitals that are referenced by Covid-19 patients by providing jamu products (curcuma, ginger, beras kencur, rosella, mangos teen skin) and extract capsules (curmino, turmeric, black cumin, and white turmeric) which have the benefit of increasing endurance for medical staff who is caring for Covid-19 patients. Jamu Iboe also wants to say that jamu is the belonging of Indonesian people which must be respected and supported in order to be a superior drink in their own country. Medical staffs should be aware of the importance of consuming this jamu to keep their health in good condition in dealing with these patients, so that they can avoid transmission of coronavirus by consuming this routine

Medical staffs become the main concern of Jamu Iboe because they are the frontline in dealing with Covid-19 patients in the hospital. They must work for 24 hours and for days in a long time, so they have a high risk of exposure to the virus. Therefore, these medical staffs must have good immune system; for example by consuming jamu. The hospital is welcomed the assistance provided by jamu company Inc. Besides being given to hospitals, jamu product assistance is also given to foundations, associations, and ojek online (online motorcycle taxi drivers). The target selection for assistance is based on what is considered most in need by Public Relations of Jamu Iboe. The poster with the tagline "Bersatu Cegah dan Lawan Corona" (Unite to Prevent and Fight Coronavirus) invites all people to obey the orders from the government so that Covid19 can be resolved immediately.

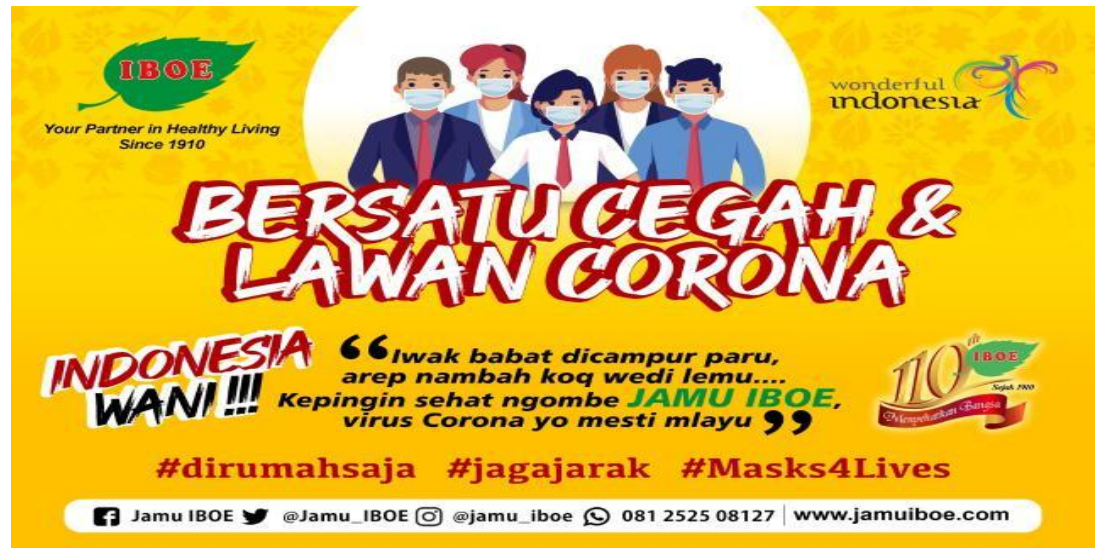

Figure 1. The poster of "Bersatu Cegah dan Lawan Corona” (Unite to Prevent and Fight Coronavirus) (source: jamuiboe.com)

In a sequence of campaign programs, jати company also supports the movement to wear a mask by creating the campaigns on social media with has tag \#Masks4Lives. This is one of the company's efforts in preventing Covid-19. This movement is expected to make society aware of the importance of wearing masks when leaving the house and as a form of avoiding the transmission of the coronavirus (Kusumo et al., 2020). The more people who care and adhere to this orders, it will be able to help prevent the spread of the Covid-19. The jamu company involves young people in his campaigns. Posters were spread on social media and on several occasions, Product Group and Public Relations Manager of Jamu Iboe (Perry Angglishartono) conveyed the program to communities and associations. 

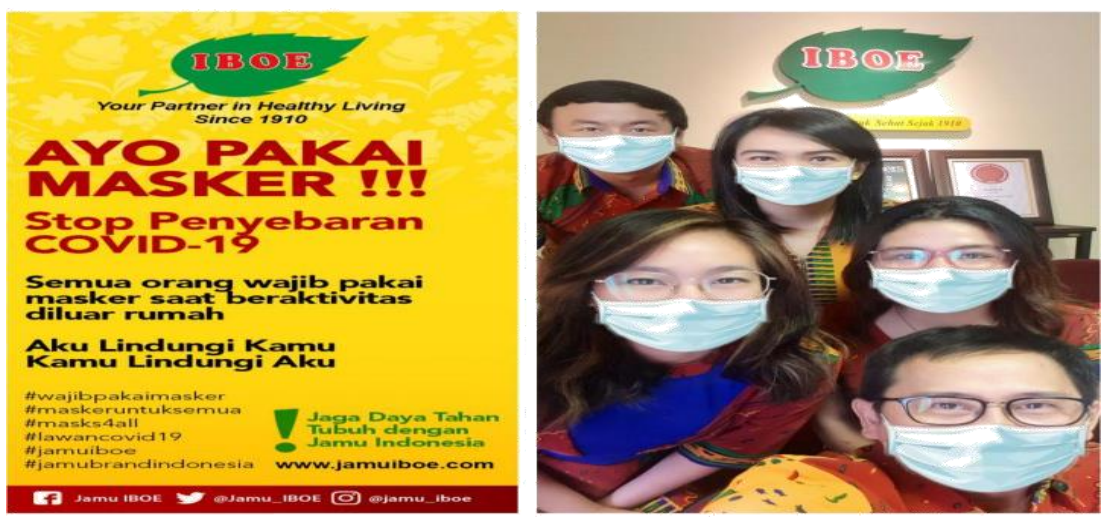

Figure 2. The poster of "Ayo Pakai Masker" (Let's Wear a Mask)

(source: jamuiboe.com)

The second poster has the main tagline "Ayo Pakai Masker" or Let's Wear a Mask. The next program is to make a competition through social media to Stay at Home or Go out with Mask Challenge. As a form of a campaign to keep the society at home, Jamu Iboe held a competition on one of the smart phone applications namely Tiktok with interesting prizes. The concepts that is determined by Jamu Iboe such as solo dance, group dance with a maximum of three people based on the rules of physical distancing, making the most creative movements, using the Jamu Iboe product attributes (Curmino, Natural Drink Curcuma, Natural Drink Ginger), and those must have originality content to get more point. The strategy is considered to be able to move the millennial and also the family because the use of Tiktok is booming in society. Tiktok is liked by all people because it is not only for entertainment, but can also be used as a forum for creativity and interesting ideas from the society.

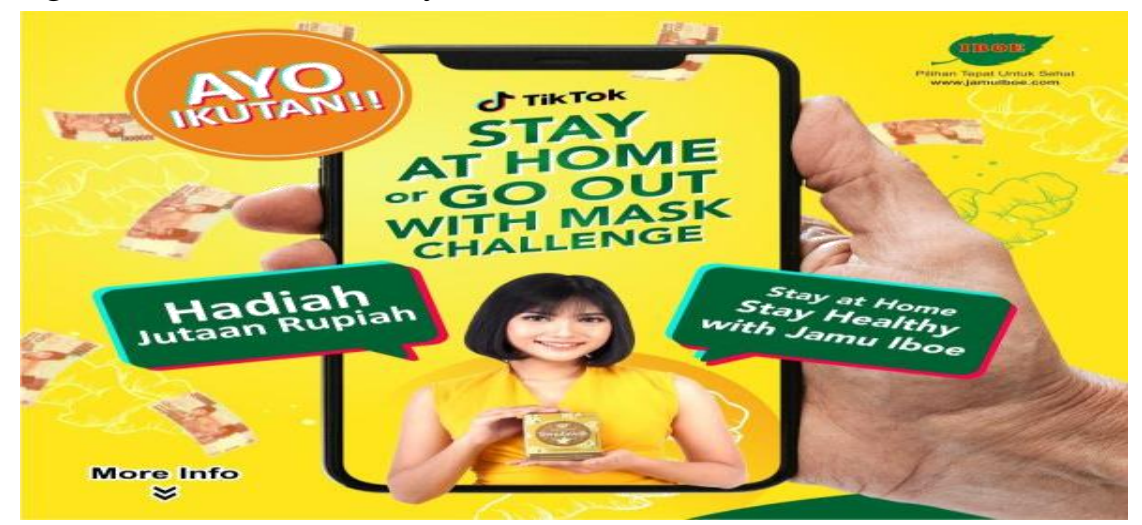

Figure 3. The poster of Stay at Home or Go out with Mask Challenge (source: jamuiboe.com)

The requirement that the Tiktok contest participants bring Jamu Iboe products indirectly conveyed a message to them to consume jamu for endurance during the Covid-19 pandemic. During the campaign, there were almost no obstacles encountered by the public relations. The more people who contribute to the program, the more effective the campaign will be. Physical distancing makes the campaign to consume jamu by online.

Public Response towards Jamu Products

Previously, some people considered that jamu was a traditional drink that was only consumed when there were health problems. In addition, the millennial perception of jamu still tends to be negative such as old-fashioned, bitter, ancestral products, not cool, 
and so on. This is because indeed the existence of jamu among them is not so interest. Jamu is not an option for young people; they prefer to take medicine, although it also tastes bitter. Not all jamu tastes are bitter, but the stigma is inherent in young people who make them reluctant to drink it, moreover make it as a daily consumption product to maintain the immune system. Therefore, jamu is an avoided drink. Product Group and Public Relations Manager at Jamu Iboe (Perry Angglishartono) said that it took a long time to change the negative stigma of the society so that slowly jamu could be accepted among the people, especially the younger generation.

During the Covid-19 pandemic, jamu made from empon-empon (various raw materials and herbs such as ginger, turmeric, ginger, and curcuma) suddenly sought after by many people. Those herbal products are used as supplements to help increase endurance, especially those made from curcuma, ginger, turmeric, and black cumin. Even the raw material called empon - empon which is usually used as a flavor in cooking, is currently highly sought after by the public. That is because empon-empon is indeed considered beneficial to health. The large number of people who are looking for emponempon could make the price of raw materials rise in the market even though the condition did not long last, because Indonesia is a country that produces empon-empon. Toga (home-grown plants that have medicinal properties, usually jamu) which is widely planted in the household environment can also be a movement that makes it easy for empon-empon to be found.

In addition, during the Covid-19 pandemic, many domestic industries and Usaha Mikro, Kecil dan Menengah (Micro, Small and Medium Enterprises) suddenly produced jamu for sale both offline and online. Many similar businesses have sprung up in the midst of this epidemic, because many people need to consume products from emponempon. Sometimes those new domestic industries also do not use production permits from the government, which usually must be used for food and beverage products. sales and a relatively easy production process supported by easily found the materials. Not only those industries which produce jamu, cafes and stalls which originally only sold coffee or tea, are now adding herbs to the menu.. There are those who sell packaged brewed jaтu and some use empon-empon mixed with drinks provided there.

Jamu Iboe strives to fulfill the consumers' need such as from the type of product sought, where to find the product, as well as the best service. The strategy used to attract millennial interest to be interested in jamu is to position it as part of a lifestyle. To realize that strategy Jamu Iboe designs the jamu stalls and makes the product packaging more modern with bright colors, which will be favored by the younger generation. Jamu Iboe also made the concept of jати bar, thus making it a new distribution connector and means of publication that could be more familiar with its consumers. Jamu Iboe also made the concept of jamu bar, which is intended that Jamu Iboe has a new intermediary and means of publication that can be more familiar with its consumers. That way, people no longer consider jamu as an ancient thing, because Jamu Iboe is designed to be accepted by all people.

When Jamu Iboe cooperates in an event or bazaar, usually the society especially young people do not want to try jamu right away. Therefore, on this occasion the sample of jamu will be distributed first, so that society can feel that not all of jamu have a bitter taste as they thought. Jати given as sample is also adjusted to the segmentation of the event and the bazaar.

The impact of the Covid-19 pandemic is felt by Jamu Iboe, which has always sold a variety of jати products in interest and practical packaging. Jamu Iboe is in demand 
in the market because of this herbal products that use empon-empon as the main material has proven its usefulness to maintain the immune system. Today, many people are aware that jamu is important even though it is not a modern drink, and people in the past had a healthy body because of the frequent consuming it. Online jamu sales during the pandemic suddenly increase and the majority of online consumers are millennials. Nowadays, jати has become part of a healthy lifestyle for the society.

The research which is conducted by the Jamu Iboe Public Relations team found that according to society's opinion that jamu was not entirely an option for their medicine. However, the presence of Jamu Iboe can attract the interest of society in terms of the authenticity of taste and has practical packaging forms that are easy to carry everywhere, making it easier for all people to consume it. In this pandemic condition, Jamu Iboe is a favorite for all people, they also look for products that are easy to consume. Hopeful this expected after the end of the Covid-19 pandemic, jamu will become part of the new normal for our society.

\section{Discussion}

Јати has many properties not only as a herbal drink but also able to prevent disease, health care, recovery, fit and even for beauty. Along with its development, a new understanding has emerged in the world of medicine that everything that comes from nature will be able to provide better benefits for health than chemical or synthetic products (back to nature) (WHO, 2020).

The diversity of herbal plants in Indonesian soil makes each region have its own unique herbal concoctions. Example jamu beras kencur, kunyit asam, sinom, cabe puyang, and pahitan (Zulfikar, 2019). It's just that there are ingredients that are most often used in the manufacture of herbal medicine, namely ginger, kencur, turmeric, galangal, ginger, secang leaves and cinnamon. Apart from that, for the fresh or sweet taste of herbal medicine which tends to be bitter, there are several additional ingredients, namely tamarind fruit, lime, and palm sugar or rock sugar. However, not all herbs are processed with flavor additives, there are some herbs that are left bitter, because there is a belief that the bitter taste of herbs is an important element of the efficacy of herbal medicine (Kemkes, 2020). Sinom is a herbal drink which has been widely known and used by the community for the purpose of healing minor illness, prevent disease, and maintain body resistance and health (Haryati N, 2021).

Mangestuti Agil, one of the professors at the Faculty of Pharmacy at Unair who stated that turmeric has benefits for boosting immunity, as well as being an antioxidant and antimicrobial. In addition, ginger herbal plants are useful as immune boosters and ginger which has properties to maintain liver health. Herbal plant ingredients are processed into jати which can be used to maintain endurance and relieve symptoms of illness that lead to symptoms of corona (Chusna et al., 2021). Empon-empon plant in the form of rhizomes has benefits as an immunomodulator that can maintain the body's immune stability so that it can prevent the transmission of the coronavirus (Setiawan et al., 2018).

Mangestuti stated in an article in The Jakarta Post, that consuming herbal plants (jатu) in the form of herbs regularly has the potential to prevent the transmission of various diseases including viruses and bacteria (Setiawan et al., 2018). This statement is one of the reasons for the establishment of a campaign to drink herbal medicine, along with an education to the public as a form of action with the aim of preventing the transmission of Covid-19. 
Campaign implementation through social media has many benefits, firstly, social media is able to provide easy access for its users so that campaigners can interact digitally with the targeted public, secondly, social media is cheap and easy to reach, in this case social media for campaign implementation is not give space and time limits to interact with each other, and the three, social media have a wide outreach because people are very easy to share the content or information they get. Several features, campaign messages can be tailored to the demographic conditions of prospective voters so that they are more measurable and targeted (Juwita, 2017).

Campaign for drinking herbal medicine is carried out through social media. The consideration of using social media is so that the message conveyed can spread widely to all communities wherever they are. However, there are several things that need to be considered when conducting a campaign in order to attract the public through content on social media, first, creating a new concept or an innovation by following existing trends, so campaigners try to build closeness so that they can get attention and make the public give feedback on the message conveyed; second, focus on the targeted market is the main thing, because even though the content has been made as attractive as possible, if it is not sent to the right target, the campaign objectives will not be maximally achieved. So that when planning the campaign implementation, it is necessary to pay attention to which market to target so that campaign activities will run efficiently and the results will be maximum (Kiew, O. F et al., 2003).

The public response slowly began to change with the existence of the Covid-19 pandemic. The society's perception that jamu is not tasty, bitter, old-fashioned, and so on; nowadays it is much sought after and consumed by society. Empon-empon is sought everywhere, when they know the good properties of this plant. So that jamu company which uses empon-empon as the ingredients, provides a product that can be enjoyed by all people, its varied flavor (not just bitter) makes jати more acceptable to the society. Јати is a product that is in demand by all people in the midst of the pandemic. The society believes that jamu made from empon-empon can be used as a supplement to improve the immune system to stay healthy, so as to avoid Covid-19.

\section{Conclusion}

This research concludes that Jamu Iboe uses a special program called Corporate Communication "Bersatu Cegah dan Lawan Corona" (Unite to Prevent and Fight Corona), where jamu company supports hospitals that are referenced by Covid-19 patients through its products, so that jamu company can be useful to maintain the immune system of medical staff and to prevent Covid-19 transmission. In addition to hospitals, the assistance is also given to foundations, associations, and ojek online (online motorcycle taxi driver). The next program is "Ayo Pakai Masker" (Let's Wear a Mask) \#Masks4Lives which is a campaign movement to wear masks, the movement is carried out through social media so that followers on social media can receive the message as a concern for јати company in the Covid-19 transmission prevention campaign and participate in implementing it. Then the last program is Stay at Home or Go Out with Mask Challenge, the program is a competition by using Tiktok to attract people to take part in the campaign to stay at home, and it is made into a competition with interesting prizes. After the Covid-19 pandemic is over, it is hoped that society's habits in consuming jати can be maintained. In addition, this herbal product which is an Indonesian original product can also increase the body's immune system if consumed regularly and continuously. Јати does not cure disease, but it is used as a way to prevent 
diseases so as not infect our bodies. If the immune system is good, then we will be healthy. Many behaviors have changed in people in this pandemic era, as if people were looking for and buying all kinds of herbal products to improve their health. Hopefully these good habits will continue even though Covid-19 has passed (Kemkes, 2020).

\section{Conflict of Interest}

I certify no conflict of interest with any financial, personal, or other relationships with other people or organizations related to the material discussed in the manuscript.

\section{Acknowledgements}

The author would like to thank Jamu Iboe, and our colleagues for making this study a successful one by ensuring all the needed data are readily available.

\section{References}

Chusna, N., Mulyani, E., Priyadi, M., Irawati, A., R, D. S., \& Safitri, R. (2021). Edukasi Tentang Virus Corona dan Pembuatan Jamu Empon-Empon untuk Penanganan Virus Corona. 5(1), 11-12.

Daud, R. F., \& Aprilani, D. (2017). (NASDEM) melalui Sosialisasi Program Kampung Enterpreneur Creative (KECE) untuk Meningkatkan Kesejahteraan Ekonomi (Studi Pada Calon Gubernur Lampung Mustafa). 249-263.

Eapen, J. T. (2021). Matily herbal drink could be a prophylaxis and therapy against COVID-19: a possibility. International Journal of Research in Medical Sciences, 9(2), 651.

Fernandha, A. (n.d.). Digital Campaign Ngobrol Projoct Oleh PT.XL Axiata Tbk. 1935.

Firmansyah, M. A., Karlinah, S., \& Sumartias, S. (2017). Kampanye Pilpres 2014 dalam Konstruksi Akun Twitter Pendukung Capres. Jurnal The Messenger, 9(1), 79. https://doi.org/10.26623/themessenger.v9i1.430

Gbadamosi, I. T. (2020). Tay safe: helpful Herbal remedies in Covid-19 infection. African Journal of Biomedical Research, 23(2), 131-133.

Handes. (2019). Public Relations dan Corporate Communication. IAIN Pontianak.

Hayuningrat, \& Chandra, G. (2019). Perancangan Kampanye Digital "Soya c(o)u(l)ture." ISI Yogyakarta.

Juwita, R. (2017). Media Sosial dan Perkembangan Komunikasi Korporat. Jurnal Penelitian Komunikasi, 20(1), 47-60. https://doi.org/10.20422/jpk.v20i1.136

Kemkes. (2020). Ayo Minum Jamu, Ayo Sehat dengan Jamu. Kementerian Kesehatan Republik Indonesia.

Ketter, E., \& Avraham, E. (2012). The social revolution of place marketing: The growing power of users in social media campaigns. Place Branding and Public Diplomacy, 8(4), 285-294.

Kiew, O. F., Singh, R., Sirisinghe, R. G., Suen, A. B., \& Jamalullail, S. M. S. (2003). Effects of a herbal drink on cycling endurance performance. The Malaysian Journal of Medical Sciences: MJMS, 10(1), 78.

Kusumo, A. R., Wiyoga, F. Y., Perdana, H. P., Khairunnisa, I., Suhandi, R. I., \& Prastika, S. S. (2020). Jamu Tradisional Indonesia: Tingkatkan Imunitas Tubuh Secara Alami Selama Pandemi. Jurnal Layanan Masyarakat (Journal of Public Services), 4(2), 465-471

Lestari, A., \& Simarmata, T. (2018). Pengetahuan Masyarakat Jawa Tentang Tanaman 
Bahan Dasar Jamu Tradisional Di Desa Brohol Kecamatan Sei Suka Kabupaten Batubara. Buddayah: Jurnal Pendidikan Antropologi, 1(1), 7. https://doi.org/10.24114/bdh.v1i1.8552

Muges, M. R. (2018). Kampanye HUMAS Dinas Komunikasi Informatika dan Persandian Kota Yogyakarta dalam Membentuk Citra Positif Pemerintah Kota Yogyakarta (Studi Analisis Deskriptif Kualitatif pada Tahun 2018). IEEE Communications Surveys and Tutorials, 15(4), 2046-2069. https://doi.org/10.1109/COMST.2015.2457491

Mulyani, H., Sari, S., \& Sari, G. (2015). Public Relation. 21-86.

Namdeo, P. (2021). A Review on Herbal Immunity Booster and Nutrition-To Fight against Covid-19. J Pharm Adv Res, 4(5), 1226-1237.

Nawir, M. (2020). Jamu Tradisional Bisnis Moncer Saat Pandemi Covid-19. Kompasiana.Id.

Pahlevi, T. A. (2017). Peran Corporate Communication Grapari Telkomsel dalam Menjalankan Program Corporate Social Responsibility di Kota Samarinda. EJournal Ilmu Komunikasi, 5(1), 311-322.

Perbawasari, S., Sjoraida, D. F., \& Lestari, V. A. (2016). Proses Public Relations dalam Program Gerakan Pungut Sampah Pemerintah Kota Bandung. Jurnal Penelitian Komunikasi, 19(2), 95-108. https://doi.org/10.20422/jpk.v19i2.59

Pradana, W. E. (2019). Di Tengah Stigma Pahit, Jamu Mencari Jalan untuk Eksis. Kumparan.Id.

Setiawan, I., Suharyanto, S., \& Dianto, R. (2018). Peningkatan Pengetahuan Tentang Jamu Pada Siswa-Siswi di Sekolah Dasar Negeri 1 Boyolali. Jurnal Surya Masyarakat, 1(1), 54. https://doi.org/10.26714/jsm.1.1.2018.54-58

Sugiyono. (2015). Metode Penelitian Kombinasi (Mix Methods). Bandung: Alfabeta.

Syaifuddin. (2018). Pengaruh Strategi Komunikasi Perusahaan dan Kreasi Nilai Pelanggan terhadap Pembentukan Reputasi Perusahaan (Case Study). Knsi 2018, 770-775.

Tamara, F. S. (2017). Image Jamu Iboe Natural Drink Dalam Upaya Brand Repositioning Oleh Pt Jamu Iboe Jaya. 2017, 1-12.

Trimanah, T., \& Wulandari, D. (2018). The Perception of Perhumas Central Java Members on Principles of PR Performance in Islam. Jurnal The Messenger, 10(1), 124. https://doi.org/10.26623/themessenger.v10i1.594

WHO. (2020). WHO supports scientifically-proven traditional medicine. World Health Organization

Widiyani Roosinda, F., \& Alfraita, A. (2020). Community Campaign in the Political Meme "Nyeleneh Community" in 2019 Presidential Election. Humanities \& Social Sciences Reviews, 8(1), 539-549. https://doi.org/10.18510/hssr.2020.8166

Wiedosari, E., Suhirman, S., \& Sembiring, B. B. (2020). Pengaruh Jamu Herbal Sebagai Antioksidan pada Ayam Pedaging yang diinfeksi Eimeria Tenella. Jurnal $\begin{array}{llll}\text { Penelitian Tanaman } & \text { Industri, } & \text { 20(1), } & 9 .\end{array}$ https://doi.org/10.21082/jlittri.v20n1.2014.9-16

Zulfikar, F. (2019). Inilah Macam-Macam Jamu Tradisional Khas Indonesia. https://www.goodnewsfromindonesia.id/2019/06/26/inilah-macam-macamjamu-tradisional-khas-indonesia 